\title{
Scotland and the public health politics of independence
}

\author{
Understanding how devolution has shaped tobacco and alcohol policies should inform debates \\ ahead of the referendum
}

\author{
Katherine E Smith reader, Jeff Collin professor of global health policy \\ Global Public Health Unit, School of Social and Political Science, University of Edinburgh, Edinburgh EH8 9LD, UK
}

When the Scottish government published its white paper setting out the case for independence, Scotland's Future, ${ }^{1}$ public health policy was central to its account of the Scottish parliament's achievements. An emphasis on tackling longstanding health problems through legislation for smoke-free public places and minimum unit pricing for alcohol was unsurprising given the status of these policies as landmark achievements of devolution and the praise lavished on the commitment of successive governments to deal with health inequalities. ${ }^{2}$

The white paper depicts independence as conferring the ability "to use the full range of levers to promote good health," yet it is noticeably lacking in specific public health policy commitments. More broadly, the future of public health has received limited attention in the unfolding debates preceding the forthcoming referendum. Discussion of health issues on the pro-independence websites of the "vote yes" campaign and the Scottish National Party focuses on the future of the NHS, while BMA Scotland restricts its guidance on the implications of independence to medical education, training, and professional matters. ${ }^{3}$ An analysis of how the existing constitutional settlement has shaped developments in public health is needed to inform consideration of alternative futures.

When political devolution took effect in Scotland and Wales in 1999, it was expected to stimulate health policy experimentation across the United Kingdom. ${ }^{4}$ Although the extent to which this has resulted in substantively divergent policies is contested, ${ }^{5}$ the record of tobacco and alcohol control in Scotland illustrates the scope afforded for innovation. As well as being the first place in the UK to implement legislation for smoke-free public places, Scotland has taken exploratory steps towards shaping the supply of tobacco and alcohol products. It has done this through the introduction of a register of all retailers selling tobacco products, a public health supplement (or levy) on larger retailers that sell both tobacco and alcohol, and a law to make proxy sales of tobacco products to those under 18 years old illegal. ${ }^{67}$ The Scottish government's endorsement of standardised tobacco product packaging, ${ }^{7}$ and its persistence on minimum pricing, contrast starkly with the UK government's equivocations. ${ }^{8}$ The ambition to make Scotland "smoke-free" by 2034 reinforces its claims to public health leadership within the UK. ${ }^{5}$

Such policies suggest that Scottish policy makers are more comfortable than their English counterparts with pursuing state level interventions for public health. ${ }^{5}$ It therefore seems plausible that an independent Scotland, with wider powers, could bring further opportunities for a progressive public health agenda. Prospects for further public health innovation can be assessed by reflecting on the "policy window" created by devolution. ${ }^{9}$ Such windows occur when three streams coalesce: problems (such as a crisis drawing attention to a problem), policies (specific proposals), and politics (including political institutions, public opinion, and party interests).

In Scotland, poor performances in international comparisons of population health and health inequalities have undoubtedly highlighted public health as a policy problem..$^{10}$ Health professions and advocacy groups arguably have a stronger influence in Edinburgh (and Cardiff) than in Westminster, reflecting smaller policy communities and a more accessible policymaking system. ${ }^{4}$ The exposure of policy makers to policies proposed by health researchers and advocates may therefore have been greater than in Westminster, whereas exposure to opposing business interests may have been lower, given the small number of think tanks, consultancy groups, and commercial headquarters in Scotland.$^{11}$ Finally, survey data showing greater public acceptance of state interventions, ${ }^{12}$ combined with the interest of the dominant Scottish National Party in demonstrating strong leadership, suggest a favourable political stream.

Some of these factors would probably persist in an independent Scotland, including a policy concern with Scotland's poor public health and public support for state led health interventions. More speculatively, the political momentum behind innovation in public health could be partially self fulfilling, and could offer a small new state a rare opportunity for global leadership. Yet there are also reasons to question any assumption that an independent Scotland would offer increased opportunities for public health innovation. Currently, health is one of the most high profile policy areas controlled by the Scottish government, promoting its position on the policy agenda. If Scotland were 
independent, the government's expanded remit would cover fiscal policy, foreign affairs, and defence, potentially reducing the focus on public health. Moreover, the accessible and consensual Scottish policymaking system that seems to have favoured public health to date could work against it if commercial interests increase investment in political activities north of the border. Such changes could, for example, empower attempts by the whisky industry to hold alcohol policies hostage to national interests in expanding whisky exports. ${ }^{13}$

The white paper itself cannot clearly guide an appraisal of such prospects. It does suggest that the "greater scope and clearer powers" afforded by independence would lead to further strengthening of alcohol and tobacco regulation. It similarly implies that powers over taxation and advertising regulation would facilitate "a coherent and concerted approach to issues of obesity and poor diet." "Yet, the core commitment to undercut the UK government on corporation tax highlights the strategic priority of creating a business friendly Scotland, and in this context maintaining political will to prioritise the interests of public health over those of the food and drinks industry may prove difficult.

Infatuation with policy innovation can lead to an exaggeration of the real dividends of devolution for the health of people in Scotland, ${ }^{2}$ and the scope for any government to tackle the social determinants of health without control over economic policy, trade, or international relations is clearly restricted. Yet, devolution does seem to have provided public health with an important window of opportunity. It should not be assumed that this window will remain open for long, or that it would open more widely in an independent Scotland.

Competing interests: We have read and understood the BMJ Group policy on declaration of interests and declare the following interests: We have not worked on behalf of any political party, have not participated in the referendum campaign, and do not have a shared or settled voting intention with regard to Scottish independence. JC and KES are co-investigators on an ESRC seminar series (grant number ES/L001284/1) examining challenges for public and global health in tobacco and alcohol policies. KS is on the board of ASH Scotland and is currently funded through an ESRC future research leaders award (grant number ES/K001728/1). JC is a member of the tobacco advisory group for Cancer Research UK, a co-investigator at the UK Centre for Tobacco and Alcohol Studies, and receives research funding from the National Cancer Institute of the US National Institutes of Health (grant number R01 CA160695-01).

Provenance and peer review: Commissioned; not externally peer reviewed.

1 Scottish Government. Scotland's future: your guide to an independent Scotland. 2013 http://scotgov.publishingthefuture.info/publication/scotlands-future.

2 Fox DM. Health inequality and governance in Scotland since 2007. Public Health 2013;127:503-13.

3 BMA Scotland. Independence referendum 2014: implications for health—a discussion paper. 2013. http://bma.org.uk/-/media/Files/PDFs/About\%20the\%20BMA/What\%20we\% 20do/Lobbying/scottishindependenceimplications.pdf.

4 Greer S. Territorial politics and health policy-UK health policy in comparative perspective. Manchester University Press, 2004

5 Smith K, Hellowell M. Beyond rhetorical differences: a cohesive account of post-devolution developments in UK health policy. Soc Policy Admin 2012;46:178-98.

6 Scottish Government. Tobacco and Primary Medical Services (Scotland) Act 2010. www. legislation.gov.uk/asp/2010/3/contents.

7 Scottish Government. Creating a tobacco free generation: a tobacco control strategy for Scotland. 2013. www.scotland.gov.uk/Publications/2013/03/3766.

8 Collin J, Hill S. Corporate involvement in public health policy is being obscured. BMJ 2013;346:f3429.

9 Kingdon JW. Agendas, alternatives, and public policies. 2nd ed. Harper Collins College Publishers, 1995

10 McCartney G, Walsh D, Whyte B, Collins C. Has Scotland always been the "sick man" of Europe? An observational study from 1855 to 2006. Eur J Public Health 2012;22:756-60.

11 Keating M. The government of Scotland: public policy making after devolution. 2nd ed. Edinburgh University Press, 2010.

12 McCrone D. Scotland and England: diverging political discourses. In: Denes IZ, ed. Liberty and the search for identity: liberal nationalisms and the legacy of empires. Central European University Press, 2006:21-36.

13 Holden C, Hawkins B. "Whisky gloss": the alcohol industry, devolution and policy communities in Scotland. Public Policy Admin 2013;28:253-73.

Cite this as: BMJ 2013;347:f7595

๑ BMJ Publishing Group Ltd 2013 